\title{
O068: Implementation of antimicrobial copper in neonatal intensive care unit (NICU)
}

\author{
P Efstathiou ${ }^{\text {* }}$, M Anagnostakou², E Kouskouni ${ }^{3}$, C Petropoulou², K Karageorgou', Z Manolidou', S Papanikolaou', \\ M Tseroni ${ }^{1}$, E Logothetis ${ }^{1}$, Karyoti $^{1}$
}

From 2nd International Conference on Prevention and Infection Control (ICPIC 2013)

Geneva, Switzerland. 25-28 June 2013

\section{Objectives}

The aim of this study was to investigate the effectiveness of the application of antimicrobial copper alloys $(\mathrm{Cu}+)$ in a Neonatal Intensive Care Unit (NICU) in relation to the reduction of microbial flora.

\section{Methods}

At a Level III Neonatal Intensive Care Unit of a pediatric hospital, with the capacity of twenty-six (26) incubators, antimicrobial copper $(\mathrm{Cu}+)$ was implemented on touch surfaces and objects. The copper alloy contains $\mathrm{Cu}$ 63\% - Zn 37\% (Lead Low). Microbiological cultures were taken in three different time periods, before and after the application of $\mathrm{Cu}^{+}$, using dry and wet method technique.

\section{Results}

In the above NICU, the reduction of microbial flora after the implementation of the antimicrobial copper $(\mathrm{Cu}+)$ on the selected surfaces and objects was statistically significant $(\mathrm{n}=15, \mathrm{p}<0,05)$ and was recorded at $90 \%$. The pathogens isolated at high rates (CFU / ml) prior to copper implementation were as follows: Klebsiella spp., Staph. Epidermidis, Staph. Aureus, Enterococcus spp.

\section{Conclusion}

This study highlights the positive impact of antimicrobial copper $(\mathrm{Cu}+)$ and demonstrates that copper implemented surfaces and objects are effective in neutralizing bacteria, which are responsible for Health Care Acquired Infections in the nosocomial environment (HCAIs).

${ }^{1}$ National Health Operations Centre, Athens, Greece

Full list of author information is available at the end of the article
The innovative implementation of antimicrobial copper in the NICU and the significant reduction of microbial flora heralds the reduction of antimicrobial drugs use, and a possible reduction of hospital acquired infections and hospitalization time.

\section{Disclosure of interest}

None declared.

\section{Author details}

${ }^{1}$ National Health Operations Centre, Athens, Greece. ${ }^{2 " A g i a ~ S o p h i a " ~ C h i l d r e n ' s ~}$ Hospital (NICU), Athens, Greece. ${ }^{3}$ Medical School of the University of Athens, Microbiology laboratory of Aretaieio Hospital, Ministry of Health, Athens, Greece.

Published: 20 June 2013

\section{doi:10.1186/2047-2994-2-S1-O68}

Cite this article as: Efstathiou et al:: O068: Implementation of

antimicrobial copper in neonatal intensive care unit (NICU). Antimicrobial Resistance and Infection Control 2013 2(Suppl 1):068.

Submit your next manuscript to BioMed Central and take full advantage of:

- Convenient online submission

- Thorough peer review

- No space constraints or color figure charges

- Immediate publication on acceptance

- Inclusion in PubMed, CAS, Scopus and Google Scholar

- Research which is freely available for redistribution

\section{(Ciomed Central}

